\title{
Evaluation of Geological Hazards for Landuse Planning in Nabq Protectorate, Southeastern Sinai Using GIS Techniques
}

\author{
Abdel Hamid A. Taha ${ }^{1}$, Elkhedr H. Ibrahim ${ }^{1,2}$, Ahmed S. Shalaby ${ }^{1}$, Mohamed Shawky ${ }^{1}$ \\ ${ }^{1}$ Geology Department, Faculty of Science, Mansoura University, El Mansoura, Egypt \\ ${ }^{2}$ Department of Geology \& Geophysics, King Saud University, Riyadh, KSA \\ Email: ashalabi@mans.edu.eg
}

Received February 23, 2013; revised March 26, 2013; accepted April 24, 2013

Copyright (C) 2013 Abdel Hamid A. Taha et al. This is an open access article distributed under the Creative Commons Attribution License, which permits unrestricted use, distribution, and reproduction in any medium, provided the original work is properly cited.

\begin{abstract}
Nabq protectorate is one of wonderful natural places in Egypt. It is characterized by diversity of bio-lives such as mangrove forests, coral colonies, wild life plants and migratory birds. Ongoing growth of tourism industries at Sharm El Sheikh northward into the Nabq protectorate causes severe hazards on its natural resources. The aim of the present study is to assess the present geo-environmental hazards in the Nabq protectorate. Assessment includes the analysis of satellite images, topographical, geological and other ancillary geological data using GIS technology. GIS data analyses indicate that the area is under threat from some of geo-hazards. Rough topography and mass wasting with high probability of flash flooding threaten different constructions in this area. The mobilization of coastal sand dunes, wave action and tidal currents are natural impacts on Nabq ecosystems, where moved dunes leave clay soils that are removed in some places by tropical storms increasing sea water turbidity that threaten the corals and other living organisms in the tidal flat region. The seismic activity hazard in the study area is usually active on lineaments extending parallel to the trend of the Gulf of Aqaba-Dead Sea transform fault where the Nabq protectorate occupies its southern segment. Unwise planning activities destroy the natural environmental resources in Nabq area by construction of new resorts on mangrove forests, coral colonies and raised beaches. Hazard assessment identifies land suitability and land use maps that are clearly exhibit models of traditional dams and buffer strips on coastal zone and highways as well as around the Bedouin communities which are worked on tourism and fishing. These maps are urgent in need of an assessment and rehabilitation program to mitigate geo-hazard.
\end{abstract}

Keywords: Natural Protectorates; Geo-Hazard Assessments; Land Use and Land Cover Maps

\section{Introduction}

Twenty four regions have been declared since 1983 by Egyptian government as natural protectorates [1]. The declaration defines the limits of each protected area and sets basic principles for management and preservation of its resources. The Nabq protectorate covers an area of about $600 \mathrm{~km}^{2}$; and has been declared in 1992 to keep biodiversities of the area immediately north of Sharm El Sheikh Resorts on the southwestern strip of the Gulf of Aqaba coastal zone (Figure 1). Its ecosystem involves spectacular mountains and charming beauty beach with lagoons, salt marshes and sand dunes; and is laced with gardens of coral reefs and mangrove forests that are wonderful landscapes for many tourists and visitors. Beside to their ecotourism importance, the coral reefs and mangrove forests are significant in protecting coastal zones from erosion by tropical storms [2]; and, in addition, are habitat of phytoplanktons that are nutrients of many marine bio-lives [3]. Mangroves also maintain the coastal waters clear that protect reef degradation as they are considered as silt traps holding silts in place $[4,5]$. Lagoons and salt marshes are also ecologically valuable as they are exceptionally high levels of biological productivity that are suitable for living organisms and migratory birds [6], whereas sand dunes form suitable environments for reptiles and birds to build up their holes and nests [7]. Beside to its biodiversity, this protectorate is considered to be one of the most economically important parts of Egypt, because of its mining activities and several tourist industries. Therefore, the Nabq area is witnessing, nowadays, unprecedented pressure on its natural 


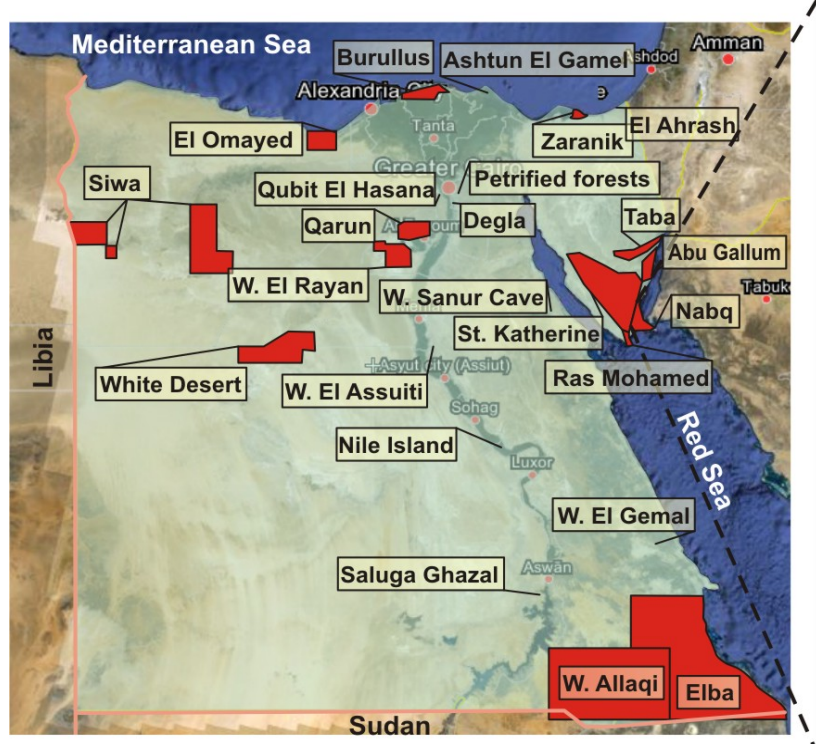

(a)

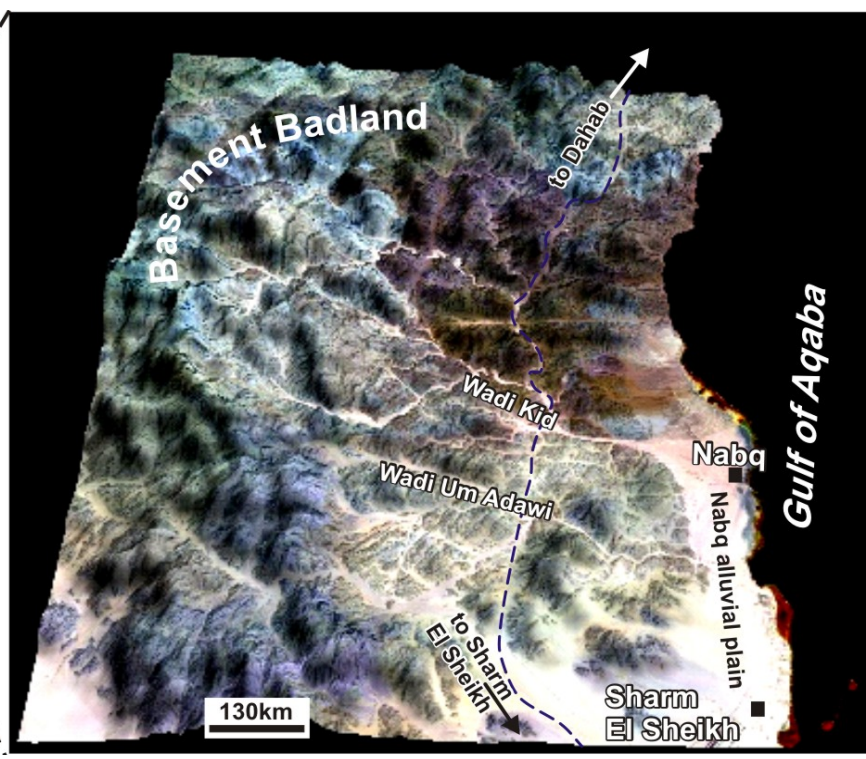

(b)

Figure 1. (a) The location map of areas of natural protectorates in Egypt involving the location of Nabq protectorate; (b) The three dimensional Digital Elevation Modeling (DEM) visualization of the Nabq protectorate showing the rugged terrain background of a wide extended alluvial plane of Nabq protectorate.

heritage resources that might threaten a complete eradication of its ecosystems.

The infrastructures of Nabq region — such as roads, diving and fishing anchors, power stations, mineral exploitation, beaches and tourist villages - are assessed in this paper to evaluate their geo-environmental hazards on its natural resources. Comprehensive assessments of natural hazard risks are also conducted to achieve safe ecosystems within the developmental plan of the area whereas urban expansion from Sharm El Sheikh Resorts towards Nabq region is predicted to cause aggravation of environmental problems in this area that might destroy its ecosystem. Resources inventory and hazards mitigation are the aims of this paper to maintain the environmental integrity of this zone by providing a geological prospective on how to preserve these natural resources, and to cover demands of tourist industry and recreation activities in Nabq protectorate.

\section{Data and Methodology}

This study uses the remote sensing technique, digital elevation models (DEMs) and GIS to evaluate the geohazards at the Nabq protectorate. The GIS and remote sensing raster map analyses aim to integrate different geological data of Nabq protectorate, which involve topographic analysis of raster, hazards, land suitability and landuse maps. The data used in this study include 1) the Landsat ETM+7 data (Figure 2(a); Path 174-Row 40 and Path 174-Row 41 of WRS-2), dated 2000; and 2) a $90 \mathrm{~m}$ SRTM DEM. These data are utilized for extraction of structural lineament, drawing the drainage network and identifying the geomorphological units. They are georeferenced to the UTM coordinate system, zone 36 north based on 1:50,000 scale topographic map [8].

The panchromatic band of the ETM+ $(15 \mathrm{~m}$ spatial resolution) was merged and re-sampled to $30 \mathrm{~m}$ using a bi-cubic convolution method. The DEM of the study area was prepared from SRTM and used digitized spot height from a 1:50,000 scale topographic map. Furthermore, tabular data such as seismic intensity and climatic data were used, and the ETM+7 satellite image was enhanced by using different processing techniques such as spatial filtering, principal components analysis (Figure 2(b)), unsupervised and supervised data analyses (Figures 2(c) and (d)), histogram equalization and rationing techniques to extract and delineate the structural lineaments and drainage network patterns. Remote sensing and GIS techniques were used respectively for the above purposes using ERDAS Imagine version 9.2, ARC GIS version 9.2 software [36]. The digital elevation model data (DEM; Figure 8(a)) is used to construct slope, aspect, painted and shaded relief maps of the Kid area (Figures 8(b)-(e)).

The area under investigation was surveyed during a reconnaissance field trip, using a topographic map at a scale 1:50,000 and ETM+7 image, which are also used to draw the drainage network and to trace the structural lineaments in the area. The seismicity distribution of the study area is evaluated during the period 1990-2005 that was obtained from the International Seismological Centre (ISC) and the Egyptian National Seismic Network (ENSN). All these data are converted into GIS database 

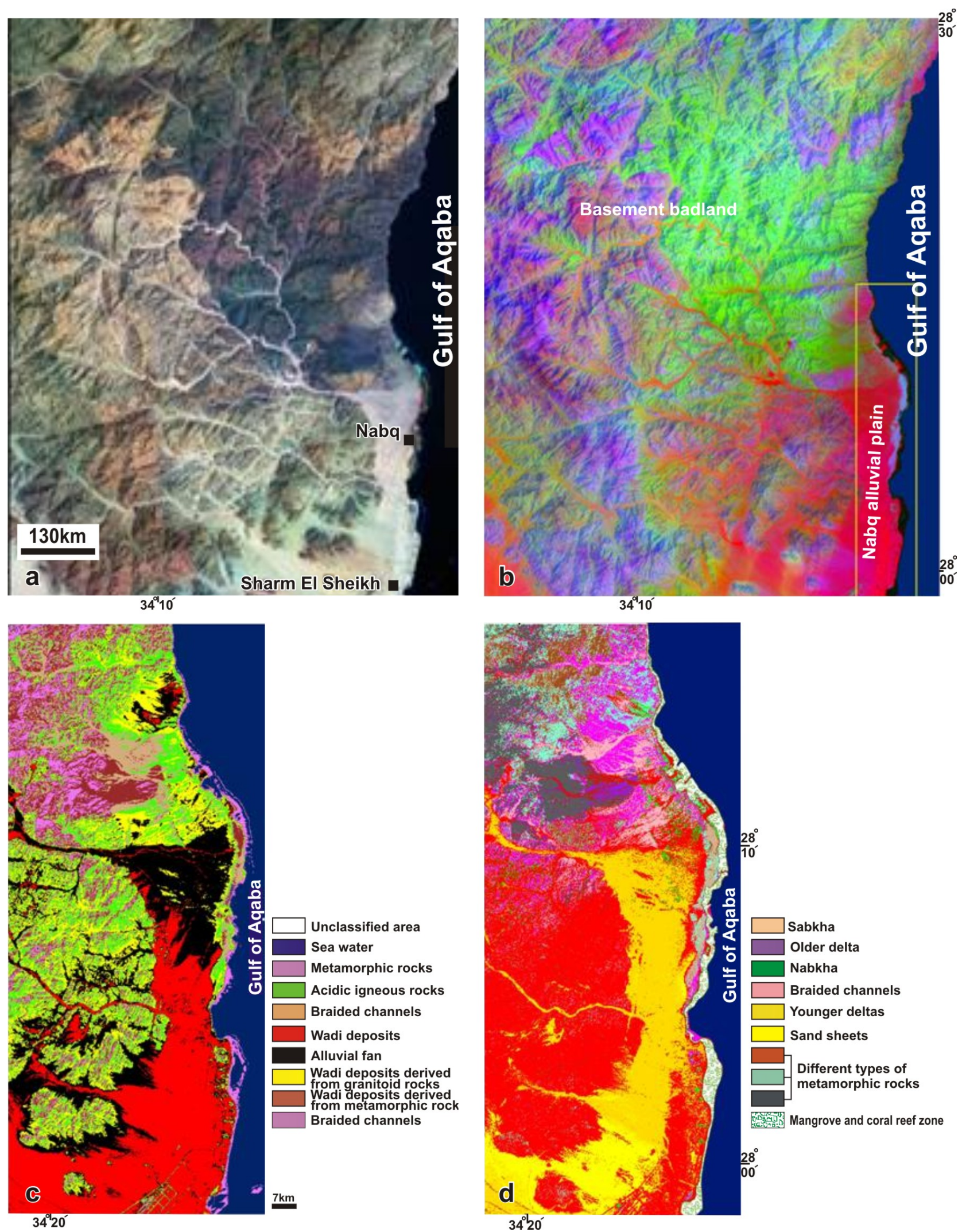

Figure 2. (a) Enhanced Thematic Map “ETM+” landsat image bands 7, 4 and 2 in red, green and blue respectively of the study area; (b) Principle component analyses is applied to the ETM+ landast image of (a); (c) and (d) Unsupervised and supervised classifications respectively applied on the "ETM+" of the Nabq alluvial plain to classify its geomorphic units. 
that are manipulated to obtain new layers that are used in constructing suitability, hazards, and landuse maps. The buffering analyses are applied on shoreline and road layers to remove distances being required away from risks that may impact their environmental settings.

\section{Geological Setting}

The geological terrane of the Nabq protectorate is characterized by basement badlands from the west; and slopes gently eastward forming the Nabq alluvial plain, with a width of about $5 \mathrm{~km}$, on the western coast of the Gulf of Aqaba (Figure 1(b)). This plain is composed of coalesced alluvial fans of several drainage systems discharging the basement terrain of the southern Sinai; the largest are Kid and Um Adawi drainage basins. This natural protectorate is characterized by arid climatic conditions, dominated by a long hot rainless summer and a mild winter. The most precipitation occurs in the form of heavy showers of a short duration forming destructive flash flooding especially in the period from December to April resulting in damage of buildings, industrial projects and businesses.

The Nabq protectorate is lithologically entirely composed of a Precambrian metamorphic belt, defined as Kid complex that involves an association of metsediments and metavolcanics; and intruded by granites and gabbrodiorite complex south-and northward of the belt respectively (Figure 3(a)) $[9,10]$. These Precambrian basement rocks are unconformably overlain by the Plio-Pleistocene fluvio-marine sediments that constitute the Nabq alluvial plain [11]. These sediments are intercalations of fluvial sand and gravels; intercalated on the coast with discrete bands of limestone enriched with shell fragments and dead coral colonies [11]. The Holocene sediments are mostly siliciclastics, characterizing the top surface of the Naqb alluvial plain as fluvial sand-gravel intercalations, which are covered by sand dunes and sheets. The Holocene evaproites occur as isolated salt marshes and sabkhas, which are formed within shallow lakes on the tidal flat region of Nabq alluvial plain [12].

The Nabq protectorate is located at the southern end of the Gulf of Aqaba-Dead Sea rift, which initiated in Pliocene as a NNE-SSW trending left-lateral strike-slip transform fault [13]. The lineament map of the Nabq area is constructed from shaded relief image that is derived from DEM data (see Figure 8(e)) showing well developed regional scale faults trending NNE-SSW and NW-SE; parallel to the structural trends of gulfs of Aqaba and Suez respectively (Figure 3(b)). The rose diagram shows that most lineaments trend in NW-SE direction, such as Khriza fault, which is predominantly characterized by normal faults with some components of right-lateral dis- placement (Figures 3(b) and (c)) [14]. The next abundant trends are oriented in NNE-SSW parallel to the trend of Gulf of Aqaba-Dead Sea transform fault that is dominated by left-lateral strike-slip displacement with some components of extension oblique to the main trend of the fault $[15,16]$; Arhab and Khezia faults are the best examples of this structural trend (Figure 3(b)). These major fault-trends form a conjugate fault system resolving NW-SE compression and NE-SW extension axes (Figure 3(d)). Two main structural grabens in Nabq protectorate are discerned; the Beida half graben and Nabq pull-apart graben (Figure 3(b)). The Beida half graben is developed with its oval-shape; occupying the area close to the outlet of Kid drainage basin. It is formed at the releasing bend of Khriza right-lateral strike-slip fault, which extends in WNW-ESE, and bends southward close to Gulf of Aqaba fault scarp into NNE-SSW direction. The Nabq graben involves the alluvial plain of Nabq protectorate. It occurs as a strike-slip pull-apart graben where it is characterized by its rhomboid shape and is bounded by NE-SW trending left-lateral strike-slip faults at its northern and southern boundaries and normal faults on the Gulf of Aqaba fault scarp at its western border.

The trend of the Gulf of Aqaba-Dead Sea rift is the most common seismic activity in Egypt over the last three decades [16-18]. The focal mechanism solution reflects normal faulting on boundaries of major basins constituting the gulf, whereas others indicate left lateral transform motion parallel to eastern and western boundaries of the rift [17]. The seismic magnitude map of the Gulf of Aqaba shows that the Nabq protectorate has the most significant earthquake magnitude of about 7 (Figure 4). This map shows also that the earthquake magnitudes trend in NE-SW and NW-SE direction, which are parallel to the trends of gulfs of Aqaba and Suez rifts respectively. The point of the intersection of these two major trends perhaps record severe zones of seismicity [17] that should be taken into consideration during mitigation and planning of an earthquake resistant design [19].

\section{Geomorphology}

In Nabq protectorate, the dry channels of drainage basins, alluvial fans, bajada plains and stream terraces indicate temporary wet climates occurred during the Pleistocene, whereas sabkhas and sand dunes are prominent landscapes characterizing the Holocene arid condition [20]. These climatic conditions sculptured the major landscapes of the Nabq area, which are grouped in three units; the basement badlands, the Nabq alluvial plain and Nabq coastal zone (Figure 5(a)). These landscapes are mapped using the supervised and non-supervised images (Figures 2(c) and (d)), which are processed from ETM+7 satellite 


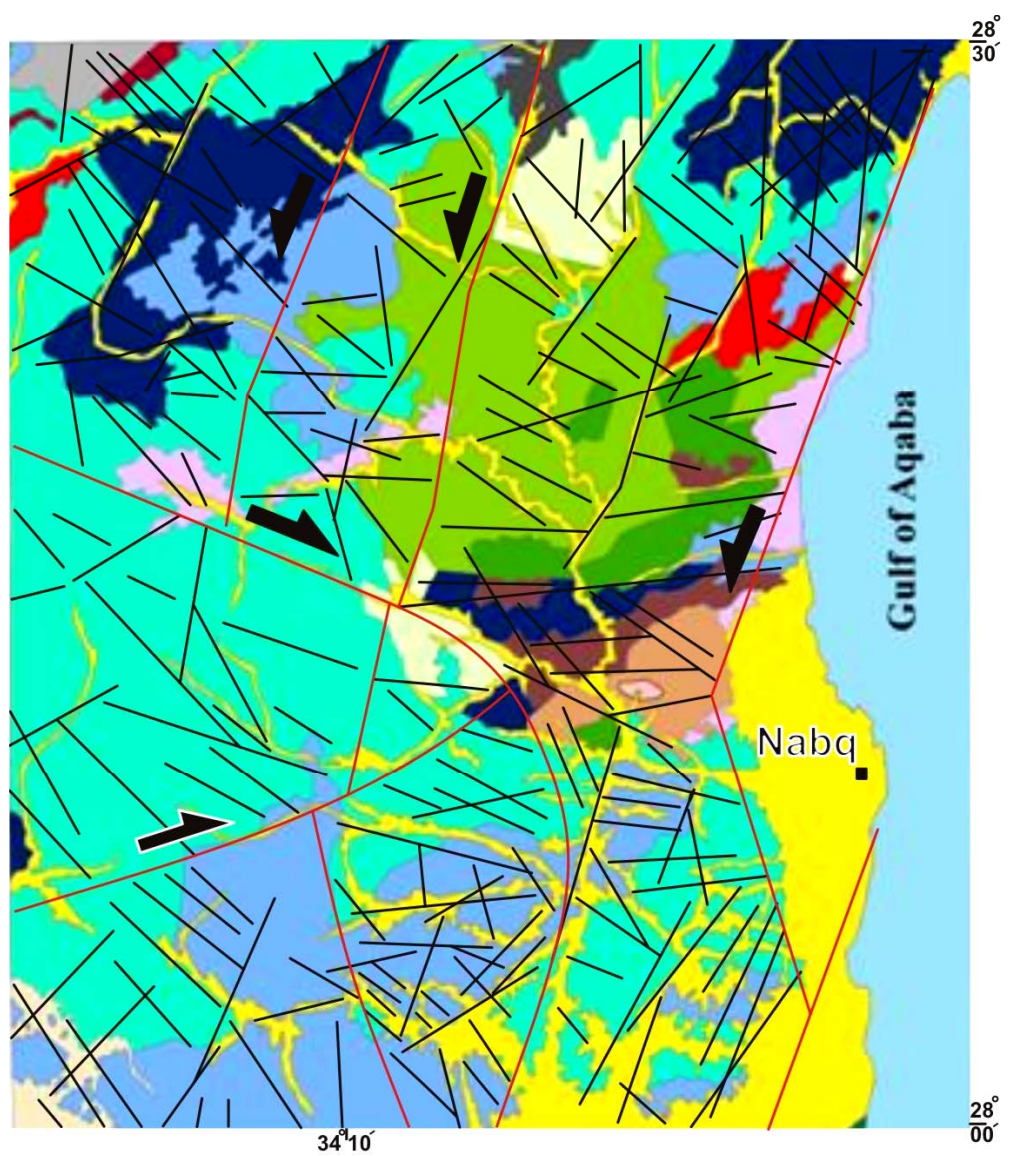

(a)

Legend

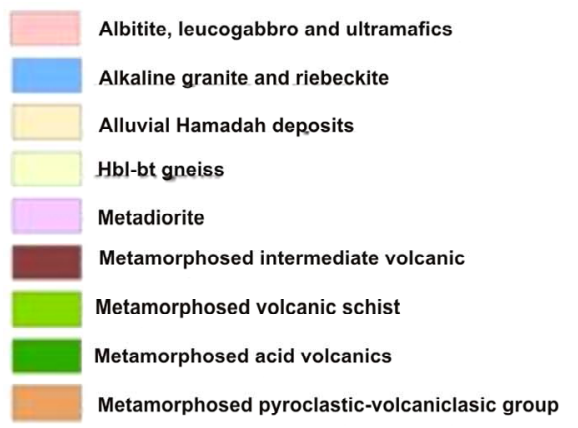

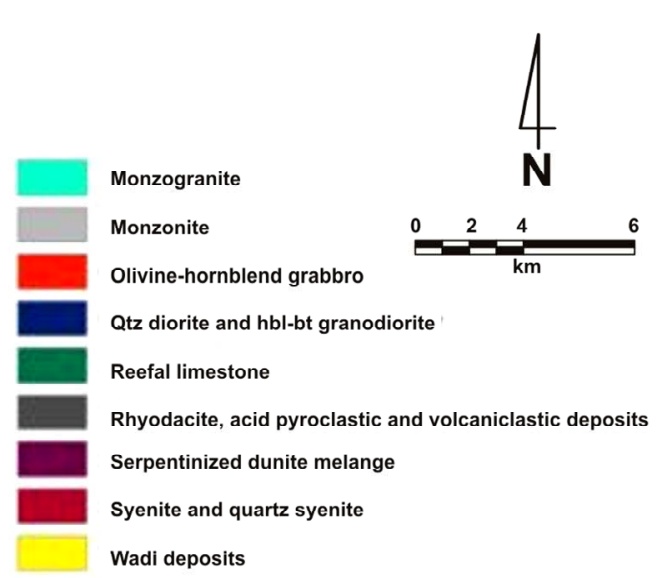

(b)

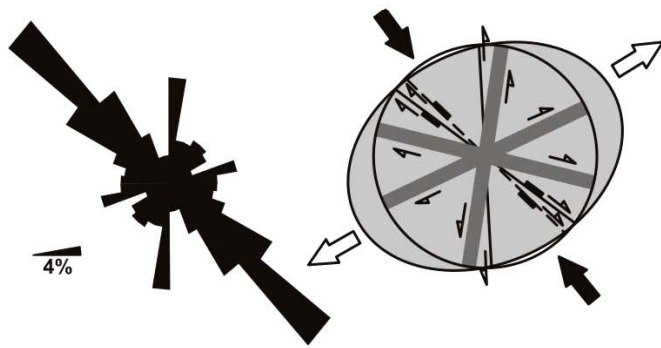

(c)

Figure 3. (a) Geological map of southeastern Sinai, modified after [8]; (b) Simplified structural map showing the main lineament trends and grabens; (c) Rose diagram showing that the prevalence of Gulf of Suez trend forming with the trend of Gulf of Aqaba a conjugate fault system; (d) The strain ellipse and fault trends showing a NW-SE trending compression axis and NE-SW trending extensional axis which develop the Gulf of Aqaba and associated basins.

image of Nabq alluvial plain (Figure 2).

\subsection{The Basement Badlands}

The geomorphic unit of the basement badlands is a characteristic landscape of southern Sinai. They are characterized by rugged topography, sharp peaks and steep slopes of high mountainous ridges. These badlands forms a prominent fault scarp, known as Gulf of Aqaba fault scarp [21], bordering the Nabq alluvial plain from the west (Figure 5(a)). This fault scarp retains recognizable straightness with linear bluffs, due to offsetting the land surfaces along the Gulf of Aqaba transform fault. This basement terrain is dissected by drainage channels of Kid and Um Adawi drainage basins, which totally empty at 


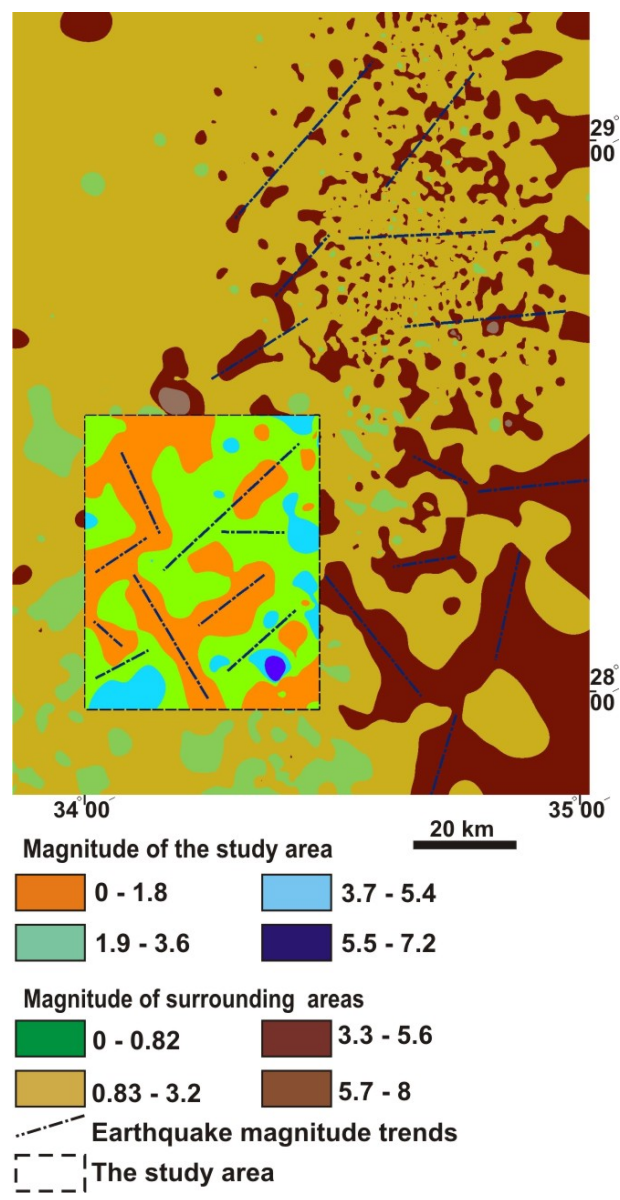

Figure 4. Seismic magnitude map of the study area and its surrounding.

the Gulf of Aqaba forming two largest alluvial fans in the Nabq alluvial plains. Talus cones, stream terraces, alluvial fans and bajada plains are common landscapes on footslopes of these badlands. The drainage system in the basement terrain is characterized mostly by dendritic, trilles and rectangular patterns indicating their relation to fault and fracture systems.

\subsection{The Nabq Alluvial Plain}

Six distinct landforms are discerned in the alluvial plain of Nabq protectorate (Figure 5(a)), which are outlined as follows:

1) The older alluvial fan occupies the northern half of Nabq alluvial plain. It is composed of boulders and cobles of granitic and metavolcanic composition. These fragments are derived from the watershed area of Kid drainage basin during Pleistocene rainy period, which are common features of other alluvial plains characterizing the western coast of Gulf of Aqaba [e.g. 21,22]. Their sediments are predominantly composed of well rounded, weakly spheroid and well-backed gravels and boulders without significant internal stratifications.
2) The younger alluvial fans occupy the southern half of Nabq alluvial plain overlying the older fan sediments with discrete contacts. The Kid alluvial fan is one of the largest alluvial fan in the western side of Gulf of Aqaba covering an area of about $21 \mathrm{~km}^{2}$ [23]. It is typically fan-shaped radiating away from the outlet of master stream of Kid drainage basin. The fan protrudes into the Gulf of Aqaba with a smoothly curved coastal outline suggesting higher amounts of alluvial sediments yielded by the Kid drainage system. In contrast, the Um Adawi alluvial fan is narrow and elongated in east-west direction, covering an area of about $4 \mathrm{Km}^{2}$. On the coast, the fan is limited by a bay. Both alluvial fans are entrenched by braided channels that are covered mostly by sand sheets.

3) Stream terraces are common landforms ornamenting the older and younger alluvial fans of Nabq alluvial plain (Figure 6(a)). These terraces occurred at three and four levels underneath the bajada plains developed on the Gulf of Aqaba fault scarp (Figure 6(b)).

4) The pediment of Gulf of Aqaba fault scarp slopes gently seaward, and is thinly blanketed with talus cones and rock-falls. Inselbergs are common landforms standing above the general level of this pediment. Bajada are widely common depositional landforms on the foot slope the Gulf of Aqaba fault scarp (Figure 6(b)). These bajada are formed of coalesced alluvial fans of small streams dissecting the Gulf of Aqaba fault scarp.

5) Nabkhas and sand sheets are eolian landforms characterizing the southern half of the Nabq alluvial plain. Nabkhas occur as piles of friable sand mounds east of Kid alluvial fan; occupying a field of about $200 \mathrm{~km}^{2}$; and are vegetated with wild-plants (Figure 6(c)). Sand sheets occupy the southern half of Nabq alluvial plain. The surface of these sand sheets is ornamented by sporadic occurrences of nabkhas with week vegetations and ill-defined drainage channels.

6) Sabkha field extends parallel to the coast of Nabq alluvial plain forming a north-south trending strip of sand covers that are encrusted by salts and anhydrites with weak vegetations (Figures 6(d) and (k)).

\subsection{The Nabq Coastal Zone}

The Nabq coastal zone is irregular ranging in width from few meters to $2 \mathrm{~km}$, and extends for about $30 \mathrm{~km}$ from Sharm El Sheikh Resorts from the south to Ras Attantour further north (Figure 5(b)). It develops the following landforms:

1) Wave-cut platforms occur at high tidal levels, and at slightly shallow depths below sea level. They develop shallow sub-marine terraces, which are composed of rock fragments and banks of coral colonies [23].

2) The Nabq beach is irregular in width, and runs parallel to the shoreline for about $20 \mathrm{~km}$. The sandy beach 

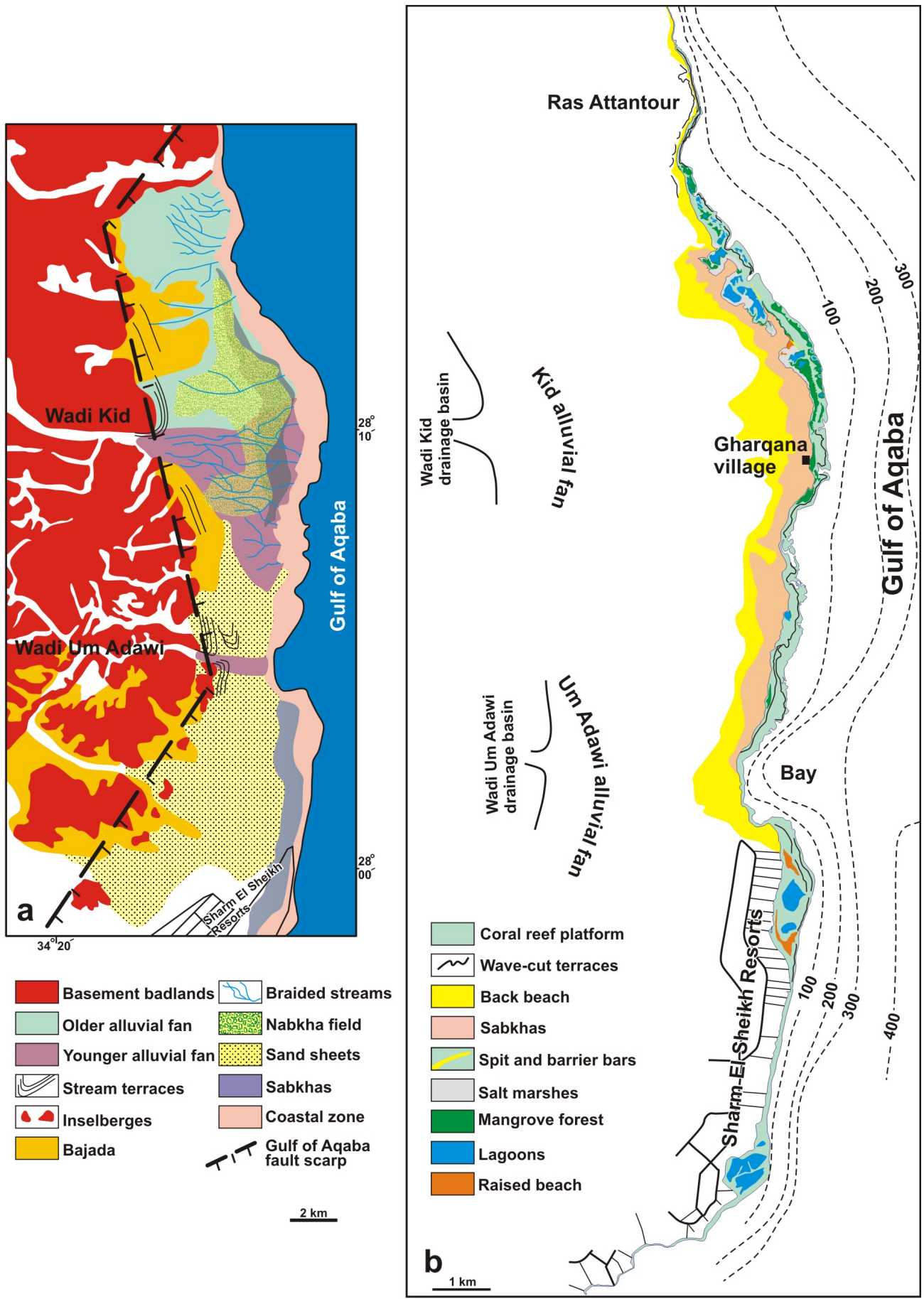

Figure 5. Geomorphic map of the Nabq protectorate (a) and its coastal area (b).

occurs backshore comprising reworked clean, well sorted and rounded sand and pebbles along a shoreline [23,24]. The rocky beaches are composed of hard and tightly backed rock fragments characterizing the foreshore of Nabq coastal zone [24]. Wave-cut terraces are developed backshore at the northern half of coastal zone, where the gently sloping old delta are degraded as discrete banks by waves (Figure 6(e)).
3) The beach cusps are common geomorphic feature on Nabq beach forming of a series of short ridges on the foreshore separated by crescent-shaped troughs spaced at regular intervals as shallow embayment (Figures 6(f) and (g)). They consist of coarse sediment at the beach face/shoreline interface and graded finer sands seaward (Figure 6(g)). The base of ridge is composed of fine sands with abundance heavy minerals whereas its surface 

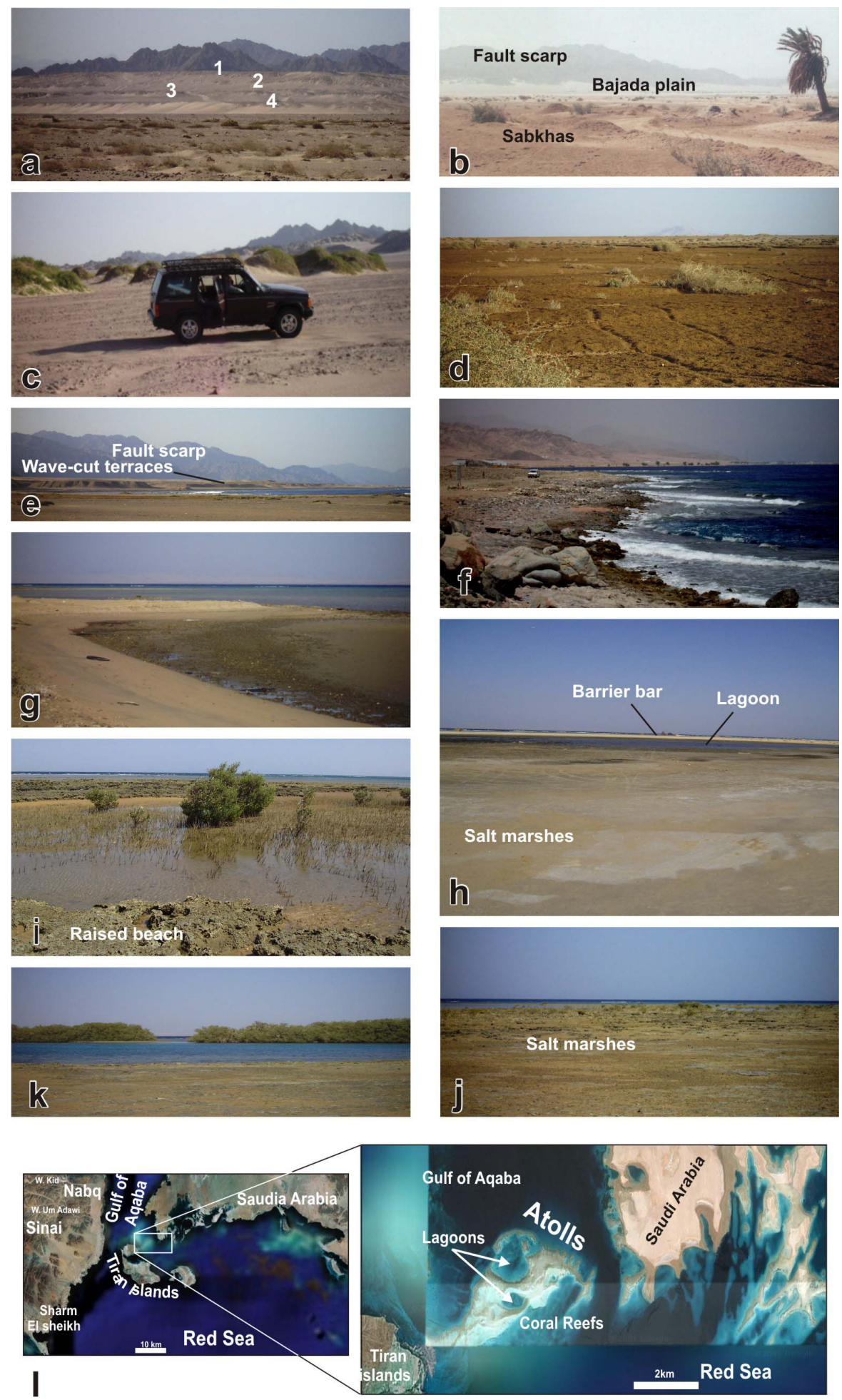

Figure 6. (a) Four levels of alluvial terraces; (b) Bajada plain formed on the Gulf of Aqaba fault scarp in the background while sand sabkhas are common on the foreground; (c) Fixation of nabkhas by natural wild-life plants; (d) The sabkha plains are weakly vegetated; (e) The wave-cut terraces on the coastal zone of Nabq protectorate; (f) and (g) Beach cusps characterize the beach of the Nabq protectorate; (h) A lagoon separated from the gulf-water by barrier bar background and salt marshes are developed foreground; (i) Raised beach of dead coral reefs bordering marshes of mangrove forests; (j) Salt marshes with sabkhas and weak vegetation; (k) Mangrove forests on a sand bar separating a lagoon from the gulf-water; (l) Tiran islands at the entrance of Gulf of Aqaba (the left hand), the magnified image (the right hand) shows the atolls from coral colonies at the boundary of these islands. 
is covered with eolian sands.

4) Spits and barrier bars are prominent landforms in Nabq coastal zone; developed as discrete sandy discontinuous trails parallel and oblique to the shoreline (Figure 6(h)). The landward behind barrier bars is formed of shallow tidal flats that involve lagoons and salt marshes, which are surrounded by mangroves and banks of coral reefs and raised beaches (Figures 6(i)-(k)). Barrier bars are commonly breached by tidal inlets that connect the sea to lagoons, which are developed in the tidal flat behind the bars, and forms elongated barrier islands. These lagoons are gradually filled with sediment and organic material, changing it landward into swamps and tidal marshes.

5) Salt marshes occur as scattered patches in the tidal flat of Nabq coastal zone covering totally an area of about $800 \mathrm{~m}^{2}$ (Figure 6(j)). These salt marshes consist of sands, mixed with shell fragments and plant remains, and encrusted by evaporits.

6) Coral reefs are exposed in the tidal flat region of Nabq coastal zone as raised beaches (Figure 6(i)). A plateau of coral beach forms the bottoms of lagoons and swamps constituting the Nabq tidal flat region. Living organisms, mangroves and algae are biological features associated with these raised coral colonies. Offshore, live coral colonies predominantly build up the continental shelf of Nabq coastal zone, and are shallowly exposed as peaks in low tide level.

7) Mangrove forests in Nabq coastal zone form unique intertidal forests of low trees and shrubs that are characterized by dense entangled networks of arched roots trapping of fine sediments, thereby promoting accretion of marshlands (Figures 6(i) and (k)).

8) Tiran island is located at the entrance of Gulf of Aqaba as a wheal-like island that is separated from Sinai by Tiran straight of about $6 \mathrm{~km}$ width (Figure 6(l)). Both sides of Tiran straight are built up of coral reef platforms as raised beaches with abundant marine notches and caves on their coasts [25]. Atolls of ring colonies of coral reefs are very common in the northern edge of Tiran island enclosing lagoons of open water (Figure 6(l)).

\section{Quantitative Drainage Analyses}

Two major watersheds contribute the alluvial plain of Nabq protectorate; the Kid and Um Adawi drainage basins covering areas of about 1014 and $358 \mathrm{~km}^{2}$ respectively. Kid drainage basin is subdivided into nein drainage sub-basins surrounding its trunk stream (Figure 7(a)). The Nabq alluvial plain itself is drained by five small drainage basins ranging in area from 20 to $38 \mathrm{~km}^{2}$ and discharge directly to the gulf.

The morphometric parameters [26] used in this study are determined from drainage networks constituting the watersheds of Nabq alluvial plain. They are drawn from four 1:50,000 scaled-topographic sheets namely; Gabal Kid, Wadi Kid, Gabal Shiekh El Arab and Gabal Sabah; provided by Military Survey of Egypt. The perimeters of drainage basins outline their topographic divide. The drainage lines were digitized and presented by Geographical Information System (GIS) to fulfill tasks of parameterization. The basin areas, and individual stream numbers and lengths, were automatically calculated by Arc Info techniques using ESRI software [27]. The morphometric parameters of drainage basins constituting Nabq alluvial plain are (Table 1):

1) Stream order $(O)$ determined by [26] as an ordering system, in which each finger-tip tributary of a stream was designated as a first order stream, two first orders combined to give a second order stream and so on.

2) Stream number $(\mathrm{Nu})$ and length $(\mathrm{Lu}, \mathrm{Km})$ are the number of stream segments and their cumulative lengths of a given order $(\mathrm{u})$ respectively [28].

3) Bifurcation ratio $(R b)$ is the ratio of a number of streams of any given order $(\mathrm{Nu})$ to a number of streams of the next higher order $(\mathrm{Nu}+1)$ [26]. Mean values of bifurcation rations are calculated for a given basin. Basins of higher bifurcation ratios tend to display elongated shapes, thereby yielding a low extended peak of surface runoff, while those of lower ratios usually display rounded shapes, therefore they have sharp peaks of surface runoff [29].

5) Drainage frequency $\left(F\right.$, Line $\left./ \mathrm{Km}^{2}\right)$ and density $(D$, $\mathrm{Km}^{-1}$ ) measure numbers and cumulative lengths of all stream segments per unit area respectively [30]. These parameters are inversely proportional to flow duration [31]. Their higher values predict sharp peak of flash flood probabilities and consequently low possibilities of groundwater recharges rather than those of lower values [32].

The $\mathrm{Rb}, \mathrm{D}$ and $\mathrm{F}$ of 15 basins (cases) are graphically plotted on the hydrogeo-morphometric cross-plot diagrams suggested by [33]. The Rb-F and Rb-D diagrams are subdivided by two boundary lines into three main classes (Figures 7(b) and (c)); Class (I) includes cases of low $\mathrm{F}$ and $\mathrm{D}$ and high $\mathrm{Rb}$ values that are favorable to contribute groundwater recharge potentialities to shallow aquifers and low probabilities of flash flood hazards. Class (II) includes cases of high $\mathrm{F}$ and $\mathrm{D}$ and low $\mathrm{Rb}$ values, which characterize cases of higher flash flooding risks and lower potentialities of groundwater recharge. Class (III) includes cases that have moderate opportunities of flash flood hazards and groundwater recharge capabilities. The diagrams show that most basins are grouped within intersection of mean-standard deviation bands of $\mathrm{Rb}, \mathrm{D}$ and $\mathrm{F}$, indicating that most basins fall within relative normal values of these parameters. Some basins do not fit similar classes in both diagrams; there- 


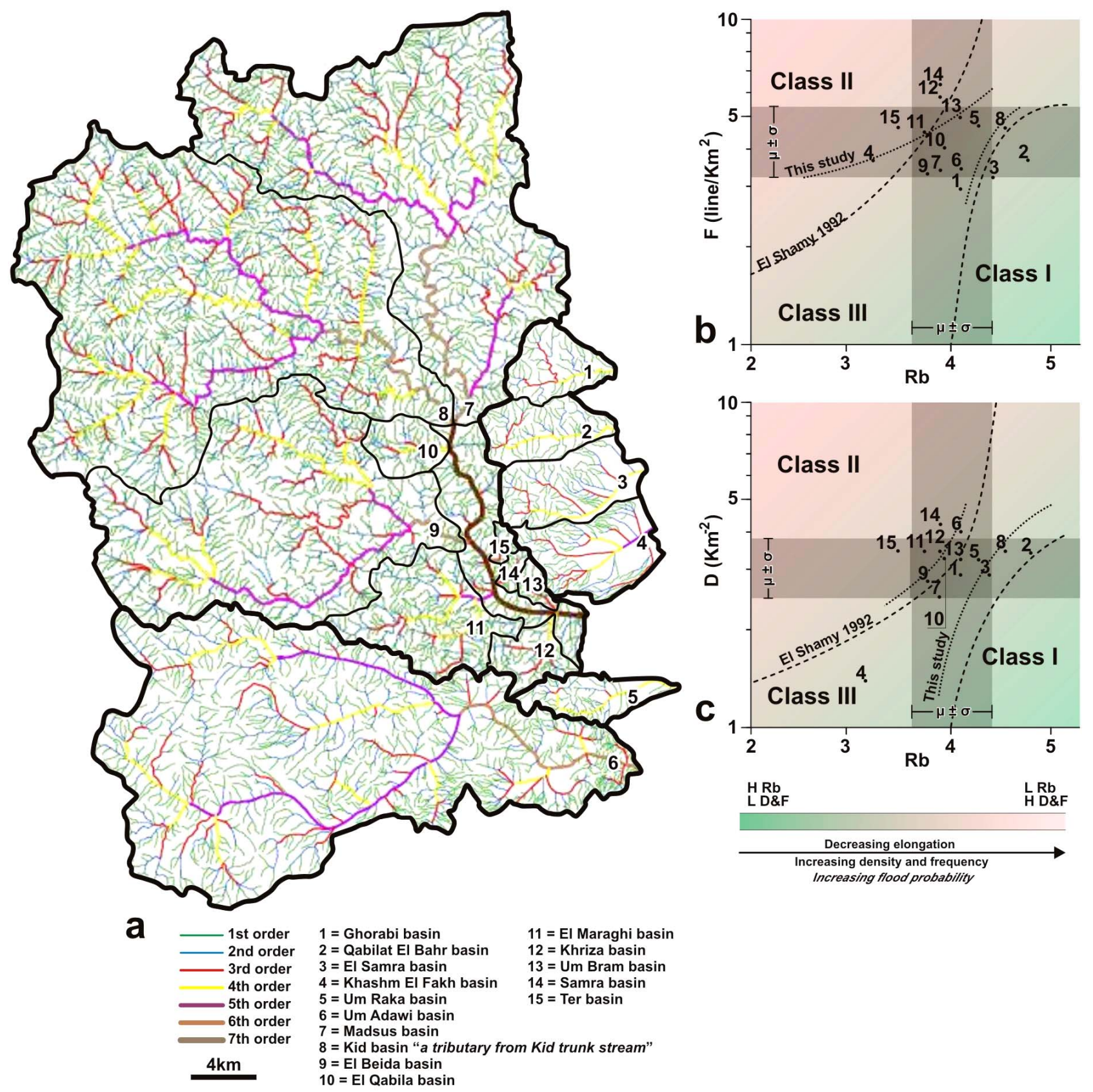

Figure 7. (a) Ordering patterns of the drainage system of the Nabq area; (b) and (c) The hydrogeomorphometric graphs of [33].

fore two new boundary best-fit lines are suggested to group same basins of similar classes in both binary diagrams. Basins No. 2, 3 and 8 are grouped within class (I) indicating their lower flash flood probabilities, while basins No. 11, 12, 14 and 15 fall within class (II) that show probable hazardous flash floods. Others fall within class (III) that involves basins of moderate flash flood hazards.

\section{Digital Elevation Model (DEM) Analyses}

The terrane slope, aspect, painted and shaded relief maps are constructed from the digital elevation model data (DEM; Figure 8(a)). The terrane slope is derived by calculating the slope at any pixel as the maximum rate of elevation changes between each cell and its neighbors [27]. The slope map (Figure 8(b)) shows that the slopes across the Nabq alluvial plain and the stream courses are low ranging between $0^{\circ}$ to $12^{\circ}$. On the mountain cliffs, the slopes ranged between $13^{\circ}$ to $25^{\circ}$ where they reach to about $85^{\circ}$ on the upper reaches of mountain fronts overlooking the main channels. 
Table 1. The morphometric data of the drainage systems of Nabq protectorate.

\begin{tabular}{|c|c|c|c|c|c|c|c|}
\hline Basin No. & Basin Name & $\mathrm{Nu}$ & $\mathrm{Lu}$ & A & $\mathrm{RB}$ & $\mathrm{D}$ & $\mathrm{F}$ \\
\hline 1 & Ghorabi & 67 & 63.51 & 22.6 & 4.11 & 2.81 & 2.96 \\
\hline 2 & Qabilat El Bahr & 94 & 83.40 & 25.9 & 4.83 & 3.22 & 3.63 \\
\hline 3 & El Samra & 111 & 101.72 & 36.2 & 4.39 & 2.81 & 3.07 \\
\hline 4 & Khashim El Fakh & 138 & 50.27 & 37.8 & 3.25 & 1.33 & 3.65 \\
\hline 5 & Um Raka & 91 & 61.2 & 19.9 & 4.27 & 3.08 & 4.57 \\
\hline 6 & Um Adawi & 1169 & 1394.2 & 352.3 & 4.08 & 3.96 & 3.32 \\
\hline 7 & Madsus & 911 & 683.5 & 280.6 & 3.87 & 2.44 & 3.25 \\
\hline 8 & Kid & 1734 & 1250.1 & 380.9 & 4.56 & 3.28 & 4.55 \\
\hline 9 & El Beida & 684 & 598.5 & 217.9 & 3.75 & 2.75 & 3.14 \\
\hline 10 & El Qabila & 60 & 47.2 & 15 & 3.94 & 3.15 & 4 \\
\hline 11 & El Maraghi & 234 & 181 & 53.1 & 3.75 & 3.41 & 4.41 \\
\hline 12 & Khriza & 75 & 50.8 & 14.8 & 3.91 & 3.43 & 5.07 \\
\hline 13 & Um Bram & 22 & 14.5 & 4.5 & 4.1 & 3.22 & 4.89 \\
\hline 14 & Samraa & 20 & 13.3 & 3.2 & 3.88 & 4.16 & 6.25 \\
\hline 15 & Ter & 13 & 9.3 & 2.8 & 3.5 & 3.32 & 4.64 \\
\hline
\end{tabular}

Abb. Nu (total stream numbers), Lu (total strea, length; km), A (basin area; $\mathrm{km}^{2}$ ), Rb (bifurcation ratio), D (drainage density; km ${ }^{-1}$ ); $\mathrm{F}$ (drainage frequency; line $\left./ \mathrm{km}^{2}\right)$

The aspect map (Figure 8(c)) determines the steepest downslope direction from each cell to its neighbors that is measured in a direction normal to topographic contour lines [34]. The major aspect trends in Kid drainage basins are consistent with the fault trends of the Aqaba and Suez rifts. The flow direction of water flood constructed from the aspect maps shows bulck eastward flow of surface runoff (Figure 8(d)).

Shaded and painted relief raster maps [27,35] visualize the morphology of Kid terrain (Figures 8(e) and (f)). These maps are achieved from the DEM through determining the local orientation of the topographic surface relative to a user-defined light source direction such as sunshine. The shaded relief map (Figures 5 and 8(e)) resolves the major structural trends described earlier in this paper. The painted relief map enhances the visualization of the surface of Kid terrain forming realistic image of its landscapes showing lower ruggdenss at the outlet of the Kid drainage basin than that laying at the water divide of the basin (Figures 5 and $8(\mathbf{f})$ ).

\section{Environmental Hazard Assyssment in Nabq Protectorate}

Seven items of geo-environmental hazards control the developmental activities in the area of Nabq protectorate. Determination of these items is based on integrations of different geological data described in this study (Figure
9). They are outlined as follows:

1) Flash flood is the most common geological hazard in Nabq protectorate. The Kid and Um Adawi drainage basins drain the basement terrain of southern Sinai that receives higher amount of annual rainfall precipitation, and is characterized by steep slopes and stream gradients [24]. It has been shown that the Dahab-Sharm El Sheikh highway occurs within the trunk stream of Kid drainage basin (Figure 9(a)), which represents a collector of surface runoff of all drainage basins of Wadi Kid. Moreover basins of higher flash flood probabilities are distributed around the trunk stream of Kid drainage basin (Figure 9(b)). Areas of moderate and low flash flood hazards characterize the drainage sub-basins of larger areas; however, they contribute surface runoff to the main channel of Kid basin. Limited occurrences of urbanization, resorts, Bedouin tents and quarry buildings are also common on both sides this highway.

2) Rough topography with higher relief and slopes are factors of flash flood and rock fall activities. The Kid drainage basin has a rugged topography at its higher extremities while the ruggedness decreases gradually to the outlet of its main channel (Figure 9(a)). Higher relief, annual rainfall precipitation and fracture densities in granites at higher extremities of Kid terrain cause severe landslides.

3) The mass wasting by rock slides, rockfalls and debris 

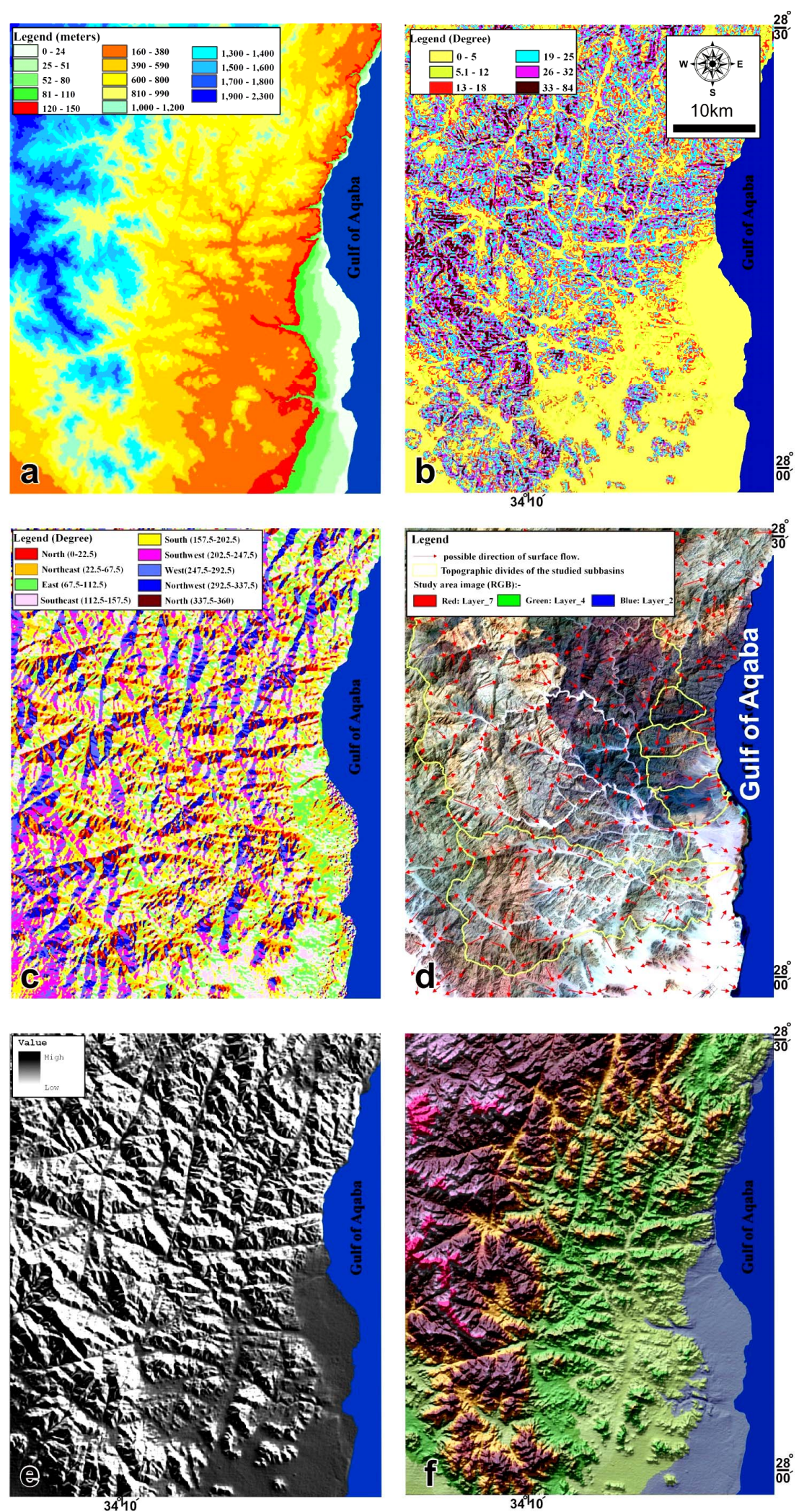

Figure 8. (a) The Digital elevation model (DEM) of Nabq protectorate; (b) and (c) The slope and aspect maps of the study area respectively, are derived from the DEM of (a); (d) The surface water flow directions derived from the aspect map of (c); (e) and (f) The shaded relief map and realistic image of the landscape of Nabq area respectively. The (f) is derived by overlaying the transparent DEM with the composite (RGB) painted relief map of the Nabq area. 


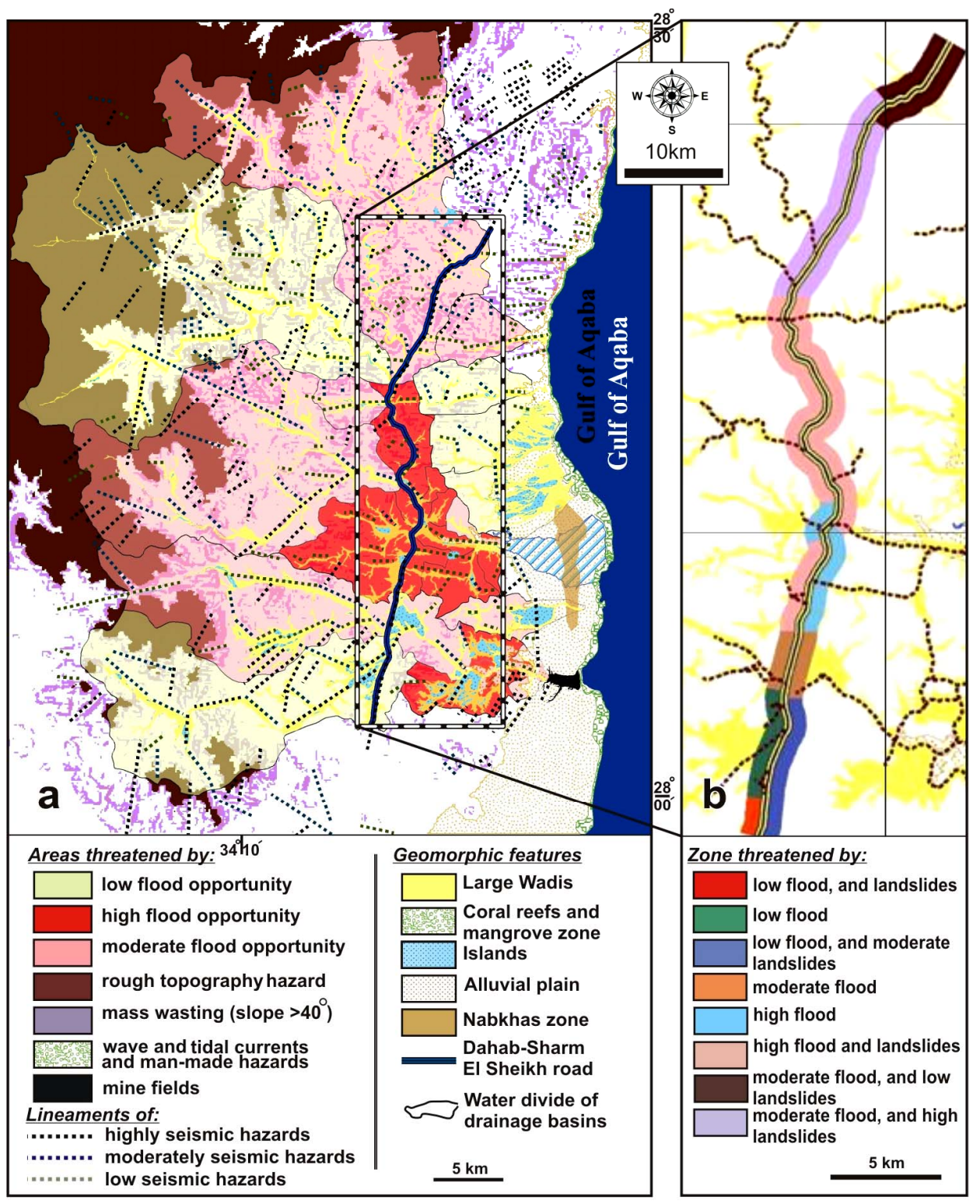

Figure 9. The hazard map of Nabq protectorate (a) and the expected different hazard items on the Dahab-Sharm El Sheikh road (b).

flows are major landslides experiencing annual severe damages in buildings and inhabitants in Kid drainage basin. The Dahab-Sharm El Sheikh highway is usually constructed closer to steeply fractured foothill slopes in the main channel of Kid drainage basin. This led to mass wasting hazards at foothill slopes. In periods of flash flood the bajada plains formed at the outlets of drainage channels debouching to the main stream of Kid drainage basin transgress actively on both sides of Dahab-Sharm El Sheikh highway. Local Bedouin communities at the rugged terrains and scarps characterizing Kid drainage basin are vulnerable to devastate rock falls and sever debris flow.

4) The wave action and tidal currents are natural im- pacts on ecosystems characterizing the Nabq alluvial plain. The tidal flat zone in Nabq protectorate possess great verities of living and dead organisms, salt marches, coral reefs and mangrove forests. The Mangroves and salt marshes require low wave-energy climates to provide suitable substrate and to keep from being physically destroyed, while reef building corals require reasonably high wave-energy environments to maintain water clarity, deliver nutrients and disperse larvae, and to remove suspended sediments to prevent their deposition in the pores of polyps [7]. Nevertheless, tropical storms especially in the winter season cause siltation-turbidity of marine ecosystem that can block light and smother corals. Widespread remnants of dead organisms are common on the 
tidal flat region of Nabq protectorate as the product of seasonal turbidity by tidal currents.

5) The nabkhas and coastal sand dunes covers about one third of the Nabq alluvial plain. These depositional landforms extend parallel to the coastal of Nabq protectorate. Their structures imply mobilization from NE to $\mathrm{SW}$, which is the mean wind-direction along the Gulf of Aqaba [24]. Nonetheless, natural fixation of wildlife plants is usually grown on the sand dunes diminishing their southward migration. Their harmful effect on both urbanization and living organisms provides desertification and stiffness of living biological ecosystems. The moved dunes leave clay soils rich in evaporites (sabkhas) that are removed in some places on the coast by tidal currents and consequently increases sea water turbidity and siltation which threaten the corals and other living organisms in the tidal flat region.

6) The seismic hazards are usually active on lineaments extending parallel to the trend of the Gulf of Aqaba-Dead Sea transform fault [17-19]. The largest Egyptian earthquake has occurred at the Gulf of Aqaba region with a magnitude of 7.2 in November 1995 [20], and the NESW trending lineaments display higher seismic activity than other lineaments trending parallel to the Gulf of Suez and Mediterranean Sea that trend in NW-SE and E-W direction respectively [37].

7) Man-made hazards by unwise planning activities threaten the natural environmental resources in Nabq area. Construction of new resorts on mangrove forests, living reef submarine terraces and raised beaches change the ecosystems of Nabq Protectorate [38]. Human sewages and excessive fertilizers due to soil reclamations in Kid alluvial plain and tremendous fishing in the Nabq area using small meshed nets are also man-made harmful destructions of corals and mangroves [5,7,39]. Explosives and field mines of ware-remains since 1973, occurred during Egyptian battles in Nabq protectorate, hindered the economical activities carried out north of Sharm El Sheikh Resorts.

\section{Land Suitability Maps}

Evaluation of the land suitability of Nabq protectorate for different environmental purposes is managed to conserve its natural resources from expanding urbanization carried out in the Nabq area and surroundings. This can be established by integration of different geological and natural hazard data. Buffer zones are suggested around areas of current residences, roads, raised beaches and bio-lives on coastal zones to provide a safe-space for their ecological conservations; and excluding zones of natural hazards from further sustainable developmental purposes. Determination of the suitable areas for a sanitary landfill involves site investigation of selected locations that are ranked according to their orders of suitability. All geoenvironmental aspects are analyzed for suitability ranking of each site (Figure 10). Ranking-zero for unsuitable, one for moderate and two for highly suitable sites - is entered to the attribute tables of the thematic data numerical field (suitability) and are processed and evaluated by the GIS. Ranking values in each field is used for suitability analyses of all relevant thematic layers, represented by thematic maps that are shaded with red, blue and green areas for zones of low, moderate and high suitability, respectively. The total suitability thematic map (Figure 11) is constructed according to suitability field of each individual thematic layer.

Although the basement rocks in Kid drainage basin are highly fractured, it devoid of surface seepages of groundwater, in contrast to other seepages from basement rocks of southern Sinai [23]. Therefore, the groundwater potentiality of the basement terrain in Kid drainage basin is ranked by zero. Most of valuable water points in southern Sinai discharge from the wadi-fill sediments characterizing the main channels of drainage basins dissecting the Sinai massif $[23,32,40]$. However, no valuable watershows are recorded in the main channels of Kid drainage basins, thus it is ranked with two because of its low probability of water supply. In contrast, the hydrogeological studies carried out in Nabq alluvial plain [41] concluded that this plain is a promising source of higher groundwater potentialities, thus ranked by one (Figure 10(a)).

It has been shown that the hydrographic drainage subbasins constitute the Kid drainage basin are classified according to their flood potentialities into three classes (Figure 10(b)). The first class involves the smaller subbasins that are located around the main channel of Kid drainage basin. This class has a weak suitability for developmental activities because of its high probability of flood peaks, thus it is ranked by zero. The second class is characterized mainly by sub-basins of moderate area that are classified in the class of moderate flood probabilities; therefore they are ranked by one. The third class involves sub-basins of low flood opportunities, thus they are ranked by two as suitable priority zones of safe flash floods (Figure 10(b)).

The mangroves and coral reefs are natural bio-lives that should be protected for further developmental activities in Nabq protectorate. Random landfill of local Bedouins and ecotourism destroy mangrove forests, coral reefs and sea grasses on the coastal zone that should be protected to conserve these bio-lives. A buffer zone of a $500 \mathrm{~m}$ width is therefore suggested around the coastal zone, which is ranked by zero to diminish future landfill activities on the coastal zone (Figure 10(c)). The land behind this buffer zone is rank by one that is suggested to be suitable for different landfills with some recommended environmental regulation rules. 

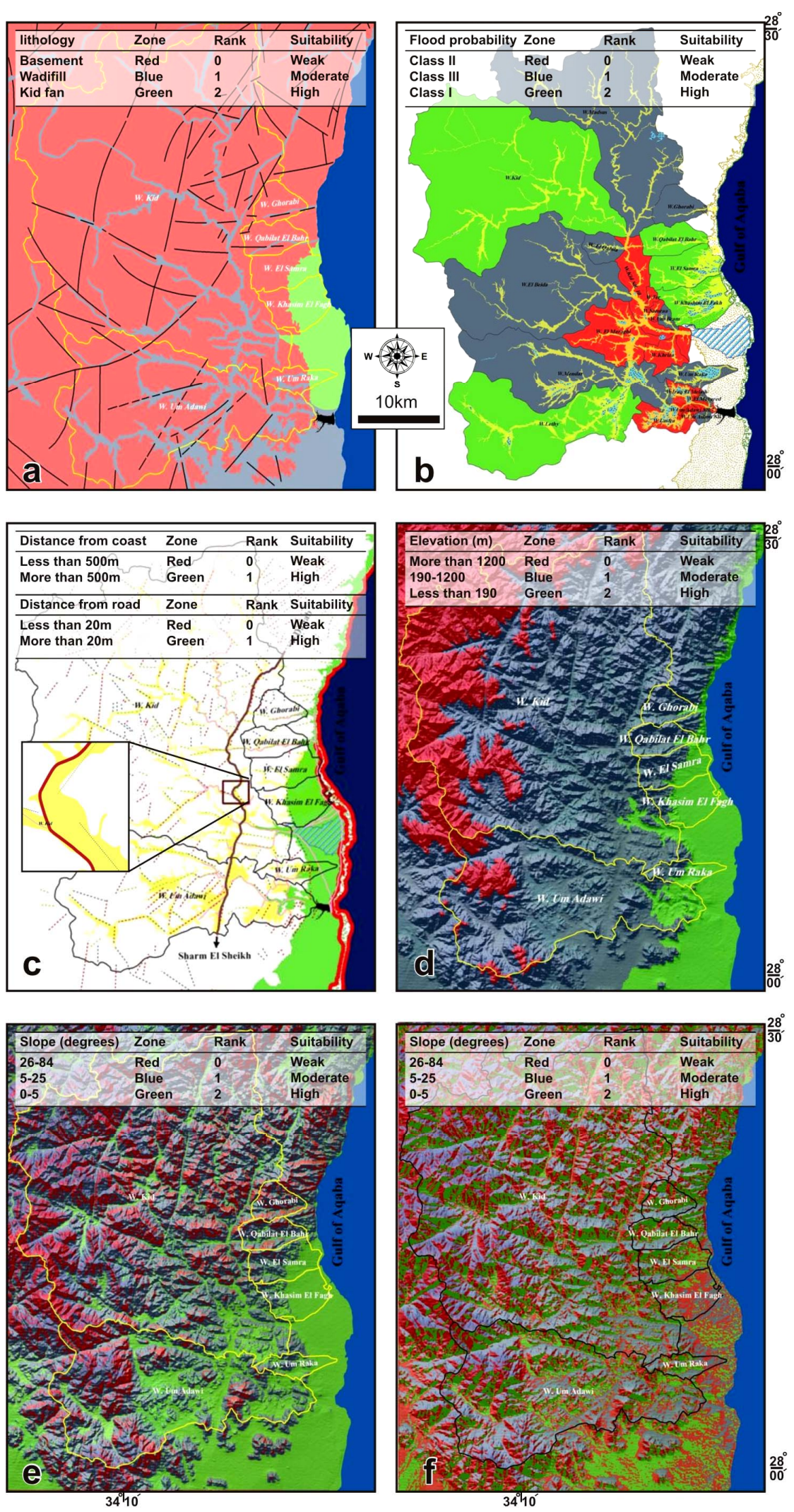

Figure 10. The suitability maps based on groundwater potentialities (a), basins of flash flood probabilities (b), coastal zone and Dahab-Sharm El Sheikh highway protections (c), digital elevation modeling (d), slope angles (e) and slope directions (f) in Nabq protectorate. Suitability rankings are attached on each map. 


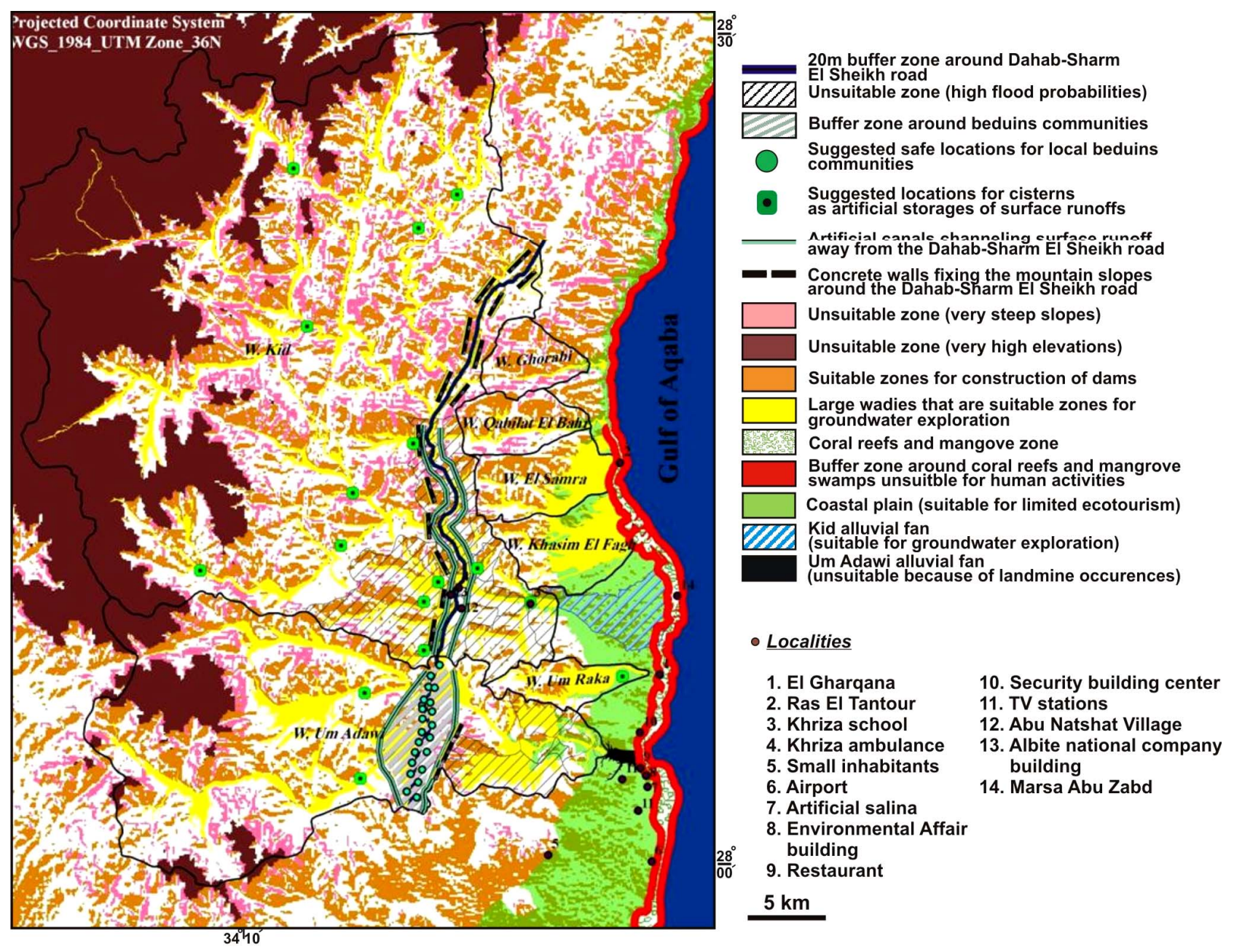

Figure 11. The suitability map of the Nabq protectorate showing suitabilities according to different purposes.

The Sharm El Sheikh-Dahab highway is a vital way connecting Taba city, north of Gulf of Aqaba, with Ras Mohamed strip to the south. Bedouin landfills and resorts are currently constructed close to this way. It passes through the main channel of Kid drainage basin that occupies the area of hazardous flash floods (Figure 9(a)). It is the ultimate channel collecting surface runoffs from all Kid drainage basins. Landslide and earthquake activities are additional natural hazards affecting this highway. The width of Kid main channel ranges between 80 to $650 \mathrm{~m}$, while the width of the paved road is about $12 \mathrm{~m}$. This permits a buffer zone of about $20 \mathrm{~m}$ on both sides of the paved road that is ranked by zero, while the area behind the buffer zone is ranked by one (Figure 10(c)).

The DEM shows that the topographic elevations of more than $1200 \mathrm{~m}$ are characterized by high ruggedness and therefore severe rock falls, thus ranked by zero, while those between 190 and $1200 \mathrm{~m}$ are ranked by one for zones displaying moderate topographic peaks and gradients (Figure 10(d)). The topographic elevation below $190 \mathrm{~m}$ is ranked by two because of its low relief and terrain ruggedness characterizing the low foothill slopes and Kid alluvial plain.

The slope is a factor of mass wasting and intensity of surface runoff, and therefore should be taken into consideration for estimation widths of buffer zones. The slope map of basement terrain of Nabq protectorate shows that the slopes between $25^{\circ}-85^{\circ}$ characterize the upper reaches of basement highs therefore they are ranked by zero (Figure 10(e)). Moderate slopes ranged between $5^{\circ}$ $-25^{\circ}$ are ranked by one characterizing lower reaches of basement ridges. Slopes ranging between $0^{\circ}-5^{\circ}$ occur usually at Nabq alluvial plain and drainage channels, which are ranked by two.

The aspect map shows that the major aspect trends of basement terrain of Nabq protectorate are due SE and S facing the Gulf of Aqaba. These trends of aspects follow the main directions of surface runoffs, which yield water enough for artificial surface water catchements; therefore they are ranked by two (Figure 10(f)). Moderate aspect trends are due $\mathrm{N}$, which are ranked by one while others are of minor aspects, and thus ranked by zero. 


\section{Landuse}

\subsection{Landuse for Water and Soil Conservation}

Traditional dams, the embankment and concrete dams [42], are constructed in the drainage basins discharging Sinai terrain in order to disperse the flash flood energy, and to conserve water by increasing amount of water infiltration, consequently improve the groundwater quality, and keep also fertile soil layer from degradation $[23,43]$. The embankment dam consists essentially of a core of impermeable materials, such as clay, and is supported by permeable shoulders of earth and rock fill. The core is coated towards the reservoir by a transition zone of sands to prevent core erosion by water seepages through the dam; however the leaked water through the core is drained out downstream by a filter of sand (Figure 12(a)). The dam is veneered upstream-side by a zone of boulders to slow down its erosion by the wave energy of water stored behind the dame. The dam foundation is built with a thin barrier, known as a cut-off structure, to reduce water leakage under the dam, thus preventing its collapse. A tunnel is built aside the dam in order to discharge the excess water stored behind the dame, and therefore avoid the water flow over the dam body. The concrete dams are built with a massive impermeable concrete blanket, and occurred in three forms; gravity, buttress and arc dams (Figure 12(b)). These traditional dams are favorable at outlets of drainage basins of hazardous flood, and in sites of shallowest bed rock that are suitable for constructing their cut-offs. Therefore, it is recommended to establish one of these dames at the outlet of Kid drainage basin and the tunnels aside the dame can convey the water, spilled out of the dame, into Bedouin communities and Nabq plain to flourish the ecological natural resources as mangrove forests.

[34] has designed a loose rocky dam; build up by

a
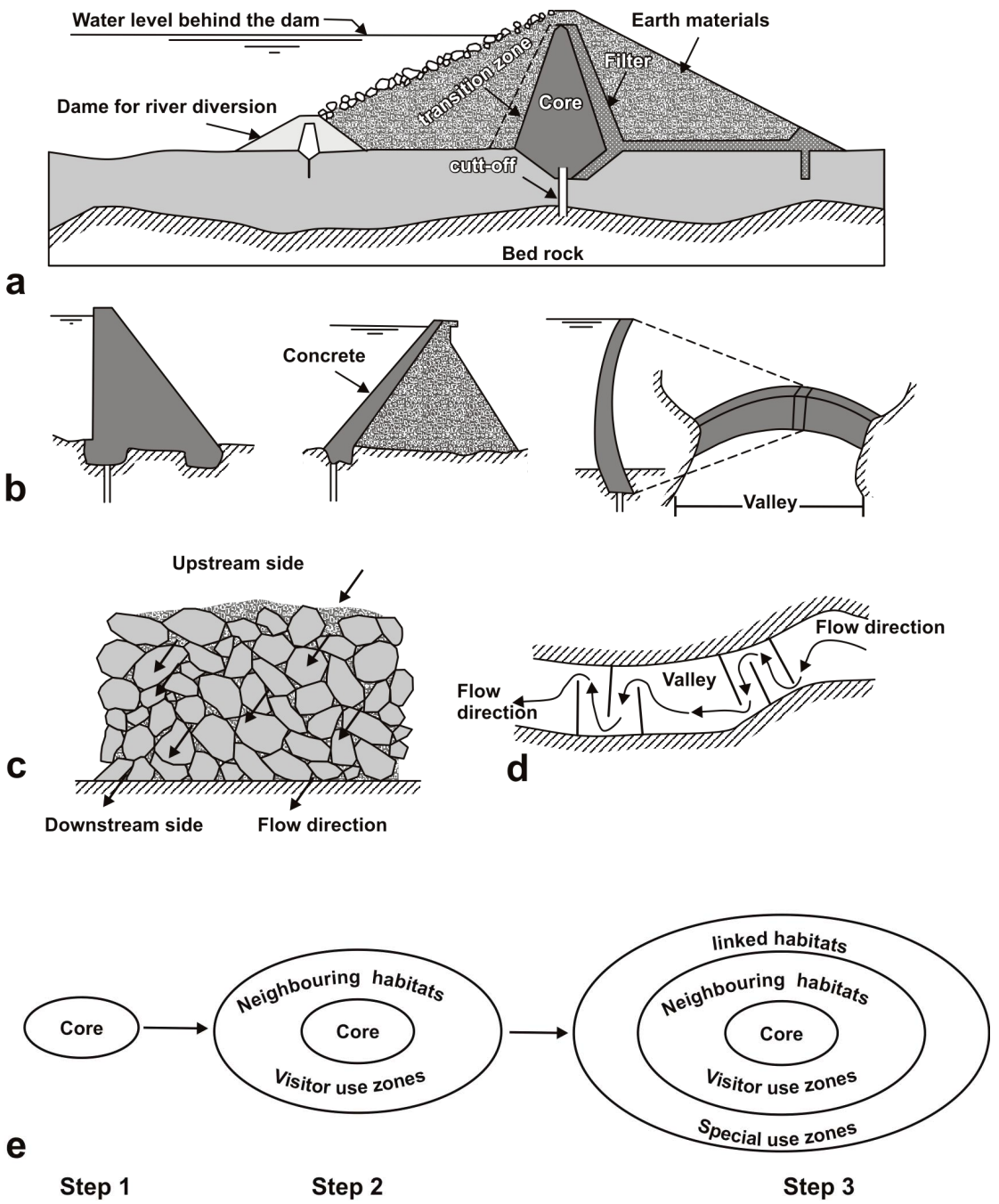

Figure 12. The designs of embankment (a) and concrete dams (b), modified after [42]. Loose bolder earth dam (c) and zigzag path of surface runoff across earth dams (d) on course of a stream, after [34]. (e) A simplified model of [6] and [7] for marine life-protection; see the text for more detail. 
available local earth materials without cementation (Figure 12(c)). The successive incomplete low rocky dams allow the water to flow in a zigzag pattern in order to reduce the flow velocity, consequently diminish the flood energy. The rocky dams should be constructed at stream segments of narrow and gentle slopes, while incomplete rocky dams are favorable in wide segments [32,34].

Cisterns are successfully constructed in front of dams to store water for livestock and other domestic uses, which can provide a family for up to one year [43]. Bedouin families in Sinai use flood waters for agriculture purposes behind rocky dames that develops usually fertile agricultural soils.

\subsection{Buffer Zones for Natural Ecological Resources}

Man-made shoreline modifications have severe impacts on biological communities in Nabq protectorate. To conserve beach organic components from ecological risks, [6] and [7] have designed a model to protect coral colonies from advanced ecological activities. In this model the colonies are rimed landward by mangroves which in turn fringe lagoons and salt marches that are usually surrounded by sand dunes. The components of this model fit into the geomorphic features of the Nabq protectorate coastal area that can be applied as follows (Figure 12(e)):

1) The core involves all ecosystems in Nabq protectorate, ranging from coral and sand dunes offshore and backshore respectively. The width of the core depends on the seaward extension of the coral reefs and the landward zone-limit of sabkhas, nabkhas, and sand dunes.

2) The first zone surrounding the core is suggested for about $50-300 \mathrm{~m}$ including habitats of environmental organization offices. This zone involves two sub-zones a) and b). The first sub-zone a) is seaward in which human activities such as fishing and recreations are prohibited to control ecosystem deteriorations. The second sub-zone b) occurs landward where sand dune mobilizations are stabilized by fences of palms and timbers.

3) The second zone of habitat includes all human activities that should be regulated to control excessive damage of ecosystems with emphasizes that permanent resorts and communities are prohibited to prevent solid and liquid wastes might delivered to the ecosystem. This zone is classified to two sub-zones a) and b) seaward and landward respectively. The sub-zone a) involves sea lanes and commercial fishing grounds, whereas the subzone b) includes safe paths for ecotourists.

\subsection{Buffer Zone for Highway}

The Sharm El Sheikh-Dahab highway runs through the main channel of Wadi Kid, and is not accessible to the shore line for environmental cautions that is only reached by a pavement track in Wadi Khriza. Recently this highway is widened to maintain two separate opposite ways; each one has about $7 \mathrm{~m}$ width and separated in some cases apart by about $3 \mathrm{~m}$ wide of artificial island and channel. Landslides and floods are the natural permanent hazards that impact this highway. Mass wasting and landslides are active on the foothill slopes of the basement rocks closely bordering the highway. The mountain front on both sides of the road should be stabilized by concrete walls to mitigate landslides and mass wasting (Figure 11). The Sharm El Sheikh-Dahab highway is threatened also by flood hazards. Traditional and rocky dames at the outlet of hazardous drainage sub-basins are recommended to mitigate hazardous floods. Digging two channels on both sides of this highway should be applied to drain floodwater away from the road sides (Figure 11).

\subsection{Buffer Zone for Bedouin Settlements and Tourist Sites}

The Nabq protectorate is inhabited with Bedouin communities, which are mostly occurred at Wadi Um Adawi on the highway and at Wadi Khriza (Figure 11). These two main sites occupy the zone threatened by higher flash floods, and fall in zones of low topographic relief and wide flood plain reach, in some places, about $3 \mathrm{~km}$ width on both sides of Sharm El Sheikh-Dahab highway. Buffer zones are recommended between these communities with a belt of timbers, rocky walls and draining channels to divert the runoff away from these communities (Figure 11). Hazardous landslides can be controlled by stabilizing the foothill slopes by covering the landslide with an impermeable membrane, directing surface water away from the landslide and draining ground water away from the landslide. Community settlements must be addressed away from the landmines in Wadi Um Adawi taking into account that these landmines may be movable by flash-floods. The valuable occurrences of groundwater discovered at the Nabq alluvial plain [41]; and the occurrence of a dug well in wadi-fill sediments of Wadi Madsus of a total dissolved salts of about 550 ppm [40] are precursors of well qualified groundwater resources that should be evaluated to be used by local inhabitants for different purposes.

\section{Hazard Mitigation Strategy of the Nabq Ecotourism}

Nabq is now considered as an alternative ecological destination of Ras Mohammad-Sharm El Sheikh Resorts. Increasing ecotourism activities in this wonderful scenery site in Egypt might damage its ecosystem treasures including mangrove forests, coral colonies. Shallow lagoons, sea grass meadows, salt marches and sand dunes, 
fishing and diving are wonderful sites for recreational tourism purposes. Safaris to hilly regions are also one of land-tourisms in Kid area. In order to safe these environmental resources with growing human activities, the ecotourism in this area should be ruled by organizations of interest. It is strictly forbidden to harm bio-forms through constructing pavement tracks to avoid destroying natural ecosystem by vehicles. Board-walks may be constructed for visitors to access the mangroves without destroying their root system and stand. The main information panel and site map should be provided on the mangrove sites. Solid waste should be treated away from Nabq protectorates, which are currently deposited across mangroves making them unsightly. Number of visitors per each trip should be controlled to diminish the negative effect of different waste materials. Motor-derived boats, diving and fishing tools should be regulated within some permission zones. Raising environmental awareness of visitors and local inhabitants for biodiversity protection should be managed with some guidelines. The on-site information guides should be located to reduce the expected negative impacts on ecosystems within minimum limits of acceptable change and to maintain the biophysical stability of the sites.

The local inhabitants participation is a safeguard of ecotourism resources, and helpful in a rationalization for environmental materials characterized by biodiversity. Bedouin villages near to the mangrove forests of Nabq alluvial plain are accessible to resorts and diving centers, and are uniqueness of biophysical sceneries, which are wonderful spots of ecological tourist destination [38]. The mangroves noticeably thrive vigorously opposite to the outlet of Kid drainage basin that might yield freshwater necessary to flourish the mangrove forests $[38,44]$. This prospects the area for future development that is regulated with conservation and protection programs [44]. Therefore, the Bedouin should be provided by awareness programs of restoring these natural resources. In addition, fishing is a source of Bedouin income that should be ruled by environmental organizations to reduce their dependency on natural resources. This will augment their income and build up their commitment to conserve bioenvironmental resources.

Sharm El Sheikh-Dahab highway passes through the main channel of Wadi Kid, but it is prohibited by the natural protectorate laws to prevent such highway to reach the Nabq alluvial plain and coastal zone where bio-lives are diverse, however, alternative paved tracks are suggested. The driving off these paved tracks is prohibited because of the fragile nature of the surrounding sand sheets and dunes and also to maintain ecosystem safe. These paved tracks truncate the suggested buffer zone of mangrove swamps and coral reefs; and are also constructed closed to Um Adawi alluvial fan which may re- sult in a serious dangerous from movable landmines present in the fan. So, it is highly recommended to adjust and restrict these paved tracks to new safe paths.

\section{Acknowledgements}

The authors thank the anonym reviewers for their comments and enhancements of the manuscript.

\section{REFERENCES}

[1] S. Baha El Din, "Towards Establishing a Network Plan for Protected Areas in Egypt. Egyptian Environmental Affair Agency," Internal Report, Cairo, 1998.

[2] R. E. Johannes, "Pollution and Degradation of Coral Reef Communities," In: E. J. Ferguson Wood and R. E. Johannes, Eds., Tropical Marine Pollution. Elsevier Publishing Company, Amsterdam, Oxford, 1975, pp. 13-51. doi:10.1016/S0422-9894(08)71107-3

[3] H. Cesar, C. Lundin, S. Bettencourt and J. Dixon, "Indonesian Coral Reefs: An Economic Analysis of a Precious but Threatened Resource," Ambio, Vol. 26, No. 6, 1997, pp. 345-350.

[4] FAO, "Mangrove Forest Management Guidelines, FAO Forest Paper 117," Food and Agriculture Organization, Rome, 1994.

[5] A. A. Ali, "Saving Egyptian's Wildlife: Renewing Damaged Soil of the Endangered Mangroves (Avicennia Marina) Grown at Nabq Protected Area, Southern Sinai," Egyptian Journal of Biotechnology, Vol. 15, 2003.

[6] R. V. Salm, "Ecological Boundaries for Coral Reef Reserves: Principles and Guidelines," Environmental Conservation, Vol. 11, No. 3, 1984, pp. 209-215.

[7] R. V. Salm, C. John and S. Erkki, "Marine and Coastal Protected Areas; A Guide for Planners and Managers," International Union for Conservation of Nature, Washington DC, 2000. doi:10.2305/IUCN.CH.2000.13.en

[8] Geological Survey of Egypt, "Geological Map of Sinai," Geological Survey of Egypt, Cairo, 1994.

[9] B. Blasband, S. White, P. Brooijmans, W. Visser and H. De Boorder, "Late Proterozoic Extensional Collapse in the Arabian-Nubian Shield," Journal of the Geological Society, Vol. 157, No. 3, 2000, pp. 615-628. doi:10.1144/jgs.157.3.615

[10] H. Furnes, A. Shimron and D. Roberts, "Geochemistry of Pan-African Volcanic ARC sequences in SE Sinai Peninsula and Plate Tectonic Implications," Precambrian Research, Vol. 29, No. 4, 1985, pp. 359-382. doi:10.1016/0301-9268(85)90043-9

[11] M. Abed, O. Hegab, F. El Bedewy and H. Nahhas, "Ras Mohamed National Park Sector Development Project," Egyptian Environmental Affair Agency, Cairo, 1995.

[12] G. Friedman, "Geology and Geochemistry of Reefs, Carbonate Sediments and Waters, Gulf of Aqaba (Eilat), Red Sea," Journal of Sedimentary Petrology, Vol. 38, 1968, pp. 895-919.

[13] A. M. Quennell, "The Structural and Geomorphic Evolu- 
tion of the Dead Sea Rift," Quarterly Journal of Geological Society of London, Vol. 114, 1958, pp. 2-24.

doi:10.1144/gsigs.114.1.0001

[14] W. Bothworth, "A Model for the Three-Dimensional Evolution of Continental Rift Basins, North-East Africa," Geology of Northeast Africa, Geologisch, Rundschau, Vol. 83, No. 4, 1994, pp. 671-88.

[15] M. Eyal, Y. Eyal, Y. Bartov and G. Steinitz, "The Tectonic Development of the Western Margin of the Gulf of Elat (Aqaba) Rift," Tectonophysics, Vol. 80, 1981, pp. 39-66.

[16] M. L. Abd El Khalek, N. A. bdel Wahed and A. A. Sehim, "Wrenching Deformation and Tectonic Setting of the Northwestern Part of the Gulf of Aqaba," Journal of Geological Society of Egypt, Special Publication, No. 1, 1993, pp. 409-444.

[17] Y. Klinger, J. Avouac, L. Dorbath Abou, N. Karaki and N. Tisnerat, "Seismic Behavior of the Dead Sea Fault along Araba Valley, Jordan," Geophysical Journal International, Vol. 142, 2000, pp. 769-782. doi:10.1046/j.1365-246x.2000.00166.x

[18] A. Salamon, A. Hofstetter, Z. Garfunkel and H. Ron, "Seismotectonics of the Sinai Subplate-The Eastern Mediterranean Region," Geophysical Journal International, Vol. 155, No. 1, 2003, pp. 149-173. doi:10.1046/j.1365-246X.2003.02017.x

[19] A. K. Abdel-Fattah, H. M. Hussein and S. El-Hady, "Another Look at the 1993 and 1995 Gulf of Aqaba Earthquakes from the Analysis of Teleseismic Waveforms," Acta Geophysica, Vol. 54, No. 3, 2006, pp. 260-279. doi:10.2478/s11600-006-0020-0

[20] M. El-Hefnawy, A. Deif, S. El-Hemamy and N. Gomaa, "Probabilistic Assessment of Earthquake Hazard in Sinai in Relation to the Seismicity in the Eastern Mediterranean Region," Bulletin of Engineering Geology and the Environment, Vol. 65, No. 3, 2006, pp. 309-319. doi:10.1007/s10064-006-0044-3

[21] M. Ashmawy, A. Swedan and T. Abdel-Fattah, "Flash Flood Hazards of Drainage Basins of Sinai Peninsula, Egypt," Annals of the Geological Survey of Egypt, Vol. 23, 2000, pp. 467-489.

[22] A. Taha, A. El Refai and A. Shalaby, "Effect of the Neogene Tectonism on the Geomorphic Evolution of the Landforms in the Area Northwest of the Gulf of Aqaba," Proceedings of the 7th Conference of Geology of Sinai for Development, Ismailia, 2004, pp. 329-342.

[23] A. S. Shalaby, "Geomorphology and Hydrogeology of Wadi Watir Basin S. E. Sinai, Egypt," M.Sc. Thesis, Faculty of Science, Mansoura University, Mansoura, 1997.

[24] G. El-Turkmany, "Geomorphological Studies on the Gulf of Aqaba Coast, Egypt," Ph.D. Thesis (in Arabic), Faculty of Arts, Cairo University, Egypt, 1987.

[25] M. Abd El Galil, "Environmental Geological Studies on the Gulf of Aqaba Region, Egypt," Ph.D. Thesis, Mansoura University, Mansoura, 1995.

[26] M. Badawi, "Tiran Island-Geomorphic Study," Geography and Environment Magazine, Faculty of Arts, Monofeya University, Vol. 25, 2001.
[27] R. E. Horton, "Erosional Development of Streams and Their Drainage Basins: Hydrophysical Approach to Quantitative Morphology," The Geological Society of America, Vol. 56, No. 3, 1945, pp. 275-370. doi:10.1130/0016-7606(1945)56[275:EDOSAT]2.0.CO;2

[28] Esri, “ArcInfo Users Guide, Ver. 8.11,” ESRI, Redlands, 2001.

[29] M. A. Melton, "Geometric Properties of Mature Drainage Systems and Their Representation in E4 Phase Space" The Journal of Geology, Vol. 66, No. 1, 1958, pp. 35-54. doi:10.1086/626481

[30] A. A. Kleo, "Wadis of Jal-Az-Zor Escarpment Kuwait. A Geomorphological Analysis," Kuwait Geographical Society, Kuwait University, 1988.

[31] A. N. Strahler, "Quantitative Geomorphology of Drainage Basins and Channel Network," In: V. T. Chow, Ed., Handbook of Applied Hydrology, McGraw-Hill, New York, 1964, pp. 39-76.

[32] F. A. Hammad, "Geomorphological and Hydrogeological Aspects of Sinai Peninsula," Annals of the Geological Survey of Egypt, Vol. X, 1980, pp. 807-817.

[33] S. Abdel Mogheeth, F. Hammad and A. Abdel-Daiem, "Hydrogeological Remarks on Gharandal Basin, Southwest Sinai Peninsula," The Desert Institute Bulletin, A.R.E, Vol. 35, No. 2, 1985, pp. 309-329.

[34] Z. El-Shamy, "Recent Recharge and Flash Flooding Opportunities in the Eastern Desert, Egypt," Annals of the Geological Survey of Egypt, Vol. XVIII, 1992, pp. 323334.

[35] P. L. Guth, "Slope and Aspect Calculations on Gridded Digital Elevation Models: Examples from a Geomorphologic Toolbox for Personal Computers," Zeitschrift für Geomorphologie, Vol. 101, 1995, pp. 31-52.

[36] ERDAS, "Erdas Field Guide, Atlanta, Georgea, USA," 4th Edition, ERDAS, Inc., Atlanta, 1997.

[37] A. Alamri, F. Scholt and C. Bufe, "Seismisity and Aeromagnetic Features of the Gulf of Aqaba (Elat) Region," Journal of Geophysical Research, Vol. 96, No. B12, 1991, pp. 20179-20185. doi:10.1029/91JB02104

[38] N. Galal, "Studies on the Coastal Ecology and Management of the Nabq Protected Area, South Sinai, Egypt, Biology," Ph.D. Thesis, University of York, Yorkshire, 1999.

[39] J. Ashworth, R. Ormond and H. Sturrock, "Effects of Reef-Top Gathering and Fishing on Invertebrate Abundance across Take and No-Take Zones," Journal of Experimental Marine Biology and Ecology, Vol. 303, No. 2, 2004, pp. 221-242. doi:10.1016/j.jembe.2003.11.017

[40] A. R. Shabana, "Hydrogeologic Factors Controlling the Groundwater Occurrences in Basement Aquifers in Some Localities of South Sinai, Egypt," Bulletin of Faculty of Sciences, Zagazig University, Vol. 25, No. 1, 2003, pp. 249-270.

[41] M. Mabrouk, A. Yousef, M. Diab and M. Barseem, "Geophysical Study on the Groundwater Occurrence in the Delta of Wadi Kid, Gulf of Aqaba, Sinai," Proceedings of the 7th Conference of Geology of Sinai for Development, Ismailia, 2004, pp. 279-288. 
[42] F. Blyth and M. De Freitas, "A Geology for Engineers," 7th Edition, English Language Book Society (ELBS)/ Edward Arnold, London, 1984.

[43] Dams and Moore, "Sinai Development Study, Phase (I), Final Report, Water supplies and coasts," The Advisory
Committee for Reconstruction Ministry of Development, Arab Refublic of Egypt, Vol. V, 1983.

[44] D. Cabahug, "Community-Based Mangrove Rehabilitation and Ecotourism Development and Management in the Red Sea Coast, Egypt," FAO, United Nation, 2002. 